\title{
Management of Secondary School Principals for Poverty Reduction in Achievement of Sustainable Development Goals in Cross River State, Nigeria
}

\author{
Esther Samuel Uko*, Okoi O. Obeten \\ Department of Educational Administration and Planning, Faculty of Education, University of Calabar, Calabar, Nigeria \\ *Corresponding author: prof.estheruko@gmail.com
}

\begin{abstract}
This paper is focused on the management of secondary school principals for poverty reduction in achievement of sustainable development goals in Cross River State, Nigeria. The research design adopted for the study was survey design. The population of the study comprised 233 public secondary school principals in Cross River State. A questionnaire titled: Management of Secondary School Principals for Poverty Reduction in Achievement of Sustainable Development Goals (MSSPPRASDG) was designed by the researchers and validated by research experts in measurement and evaluation. Data collected from 233 schools were used for the analysis. Using test-retest statistics, the reliability co-efficient of the instrument was 0.85 . Weighted mean score, standard deviation and criterion mean were used to answer the research questions while $\mathrm{z}$-test was used to test the hypothesis at 0.05 level of significance. The findings revealed that secondary school principals could contribute directly towards poverty reduction in achievement of sustainable development goals by partaking in and organizing entrepreneurship skills acquisition training for members of their staff in secondary schools in Cross River State. It was therefore recommended that the State Ministry of Education (SME) and State Secondary Education Board (SSEB) should set up organ(s) that will provide support and supervision for secondary school principals to encourage effective implementation of entrepreneurship skills acquisition training programs in order to reduce poverty and achieve sustainable development goals in Cross River State, Nigeria.
\end{abstract}

Keywords: management, principals, poverty reduction, achievement, sustainable development

Cite This Article: Esther Samuel Uko, and Okoi O. Obeten, "Management of Secondary School Principals for Poverty Reduction in Achievement of Sustainable Development Goals in Cross River State, Nigeria." American Journal of Educational Research, vol. 6, no. 1 (2018): 65-69. doi: 10.12691/education-6-1-10.

\section{Introduction}

Unarguably, a strong bond and relationship between education and socio-economic development is inevitable. On this premise, it will be worthy to place education and the socio-economic development of the society as strong forces which when brought together are capable of being a panacea for poverty reduction in achievement of sustainable development goals of the nation.

The Copenhagen Declaration [1] described poverty as a condition characterized by severe deprivation of basic human needs including education, safe drinking water, sanitation, health, shelter and information. Uko and Ayuk [2] noted that many researchers in Nigeria overtime have raised concerns about the impact of poverty and its effect on the Nigerian child. To them, poverty is becoming widely recognized and takes various forms such as lack of income and productive resources sufficient to ensure sustainable livelihood, hunger, malnutrition, ill-health, limited and at times no access to education and other basic services, increased mobility and disease related mortality, homelessness and inadequate housing, unsafe environments, social discrimination and exclusion, deprivation and very unhealthy teaching and learning conditions. They termed the issue as the malaise which maligned the attainment of sustainable educational goals which must be properly addressed to enhance not only the academic programs, but equip the teachers to acquire necessary knowledge and skills to enforce poverty reduction for sustainable development goals.

Ebua [3] posited that sustainable development goals will not meet up with the objectives, if members of the society do not understand the need to implement certain strategies towards poverty reduction. The strategies include entrepreneurship and skill acquisition training programs for educational employees' empowerment, which will enhance rapid socio-economic development. Furthermore, poverty reduction can mostly be achieved if members of the society are taught on the need for independence, rather than waiting wholly on government to do everything for them.

Sustainable development was first used in a publication titled "Our Common Future", a report from the United Nations World Commission on Environment and Development (WCED). According to the report, sustainable development is defined as development that meets the needs of the present without compromising the future generations. On this premise, sustainable development strives to equip 
individuals of the society with specific skills and abilities to combat poverty, thereby reducing and possibly bringing it to extinction.

For sustainable development to be embraced as a shining path that will salvage both the present and future generations, an educational four pillar model with the rider that the human beings at the center had been developed [4].

One possible model of sustainable development indicators that will help secondary school principals for poverty reduction in achievement of sustainable development goals is as shown in Figure 1.

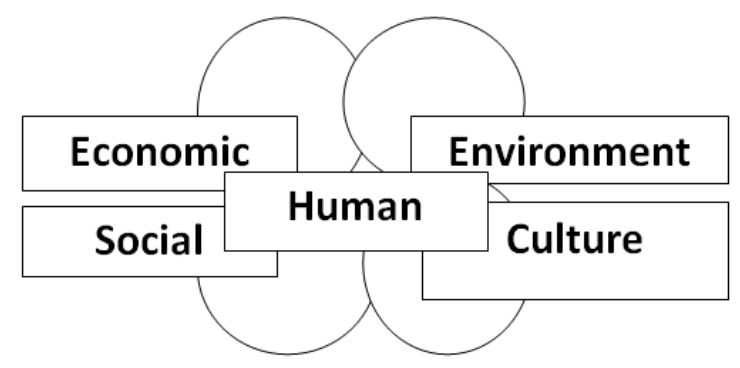

Figure 1. An Education Model of Sustainable Development [4]

Table 1. Indicators for Poverty Reduction [4]

\begin{tabular}{|l|l|}
\hline Theme & Focus Area \\
\hline \multirow{4}{*}{ Poverty } & $\bullet$ Income poverty \\
& $\bullet$ Income inequality \\
& $\bullet$ Sanitation \\
& $\bullet$ Drinking water \\
& $\bullet$ Access to energy \\
& $\bullet$ Living conditions \\
\hline
\end{tabular}

Table 1 shows that without the proper management of human beings most especially those who have been well equipped educationally, in this context secondary school principals in the inter- and intra-generational sense, there can be no sustainable development. This is so because education does not only enhance skills of poverty reduction but also deals with the awakening and nurturing of human potentials. United Nations report [5] stated that education in the developmental perspective deals with the conservation of human heritage (environmental, economic, social and cultural). The report affirmed that throughout the ages and in all climes, education involves the trans-generation of heritage.

Samuel [6] believed that Nigerian developing socio-economic structure is bound to crack and crumble under the weight of the expectations of the sustainable development goals. In addition he cited that a nation is only as strong as the forces of its entrepreneurs, most especially those who have been properly trained and prepared for challenges of entrepreneurship and business ventures.

Uko and Ayuk [2] emphasized the need for educational stakeholders to address poverty reduction due to the alarming evidence on the prevalence of poverty in Nigeria. They quoted the Federal Office of the Statistics (FOS) Publication [7] which showed that about $45 \%$ of the Nigerian Population is below the poverty line, with an estimated poverty level of about $66 \%$. Buttressing further on the need for sustainable development program on poverty reduction, they quoted the Central Bank of
Nigeria (CBN) [8] report on poverty thus, "a state where an individual is not able to cater adequately for his or her basic needs of food, clothing and shelter, inability to meet social and economic obligations, lack of gainful employment, skills, assets, self-esteem, and limited access to social and economic infrastructure such as education, health, portable water and sanitation”

Roberts [9] asserted that proper orientation of educational stakeholders, especially school principals alongside their teachers and non-teaching personnel about the need for them to be the flag bearers of entrepreneurship training and skill acquisition programs is very necessary in the bid to achieve poverty reduction for sustainable development goals. He also stated that if these human resources are properly guided and managed, they will become useful tools for salvaging the prevalent socio-economic problems in Nigeria, since these educational managers have a good knowledge of the goals that will bring about the socioeconomic development of the country.

Arinze [10] noted that educational administrators and teachers especially secondary school educational employees can be properly and positively managed for the economic, political and socio-cultural development of the society as well as the achievement of sustainable development goals before the year 2030. Furthermore, he stated that if educational administrators are equipped to be able to train the personnel working under them to acquire and practice entrepreneurship skills, it will help reduce total dependence on government.

Trance [11] expressed that in an era where opportunities for sustainable wealth creation can be easily harnessed by the introduction of entrepreneurship education into the school curriculum, so much may be achieved in terms of poverty reduction and economic growth if all teachers are involved in teaching and practicing the principles of entrepreneurship themselves by venturing and serving as evidence of financial independence and agents of poverty eradication.

Udida, Ebuara and Uko [12] stated that although education is a source of wealth creation and the development of man to acquire specific skills and abilities, the managers of educational institutions in Nigeria by certain actions and inactions have frustrated the dream of alleviating poverty through improper teaching and research. To them one of the major difficulties associated with managing poverty reduction in schools is lack of commitment on the part of the initiators and implementers (stakeholders and government).

Roe [13] stated that the State Ministry of Education (SME) should not only encourage school principals or administrators to engage their subordinates into in-service entrepreneurial skill acquisition training programs, but should ensure that they work hand in hand with government to give grants, soft loans and long term loans to educational employees who have good and verifiable entrepreneurship ideas and proposals but are handicapped in achieving them, due to lack of funding. This approach if adopted will go a long way to motivate, encourage as well as help in the achievement of sustainable development goals in Cross River State.

Uko [14] posited that school programs should be properly planned to ensure that principals with the requisite technical and organizational expertise and background are engaged. To buttress this fact, she 
suggested that Governments in Nigeria should create adequate employment and training opportunities, improve the education system and formulate policies that are people oriented with emphasis on practical skills acquisition. Nkang [15] opined that expertise by way of knowledge, skills and behavioural attributes would be readily acquired through modern educational institutions where the employees are exposed to practical entrepreneurship schemes.

\subsection{Statement of the Problem}

Educational administrators or school principals are seen as agents of positive change in every society. Poverty is a clog in the wheel of attainment of the agenda of sustainable development goals. This can only be combated by timely, proper and strategic intervention by educated minds, intellectuals and members of society who are willing to fight and win the challenges that might present themselves.

Poverty reduction can't be achieved if educational stakeholders, especially school administrators are not used as agents of change which will cut across both urban and rural communities. The presence of school administrators working in almost all communities in Cross River State and Nigeria as a whole could provide an opportunity for government and corporate educational bodies responsible for making decisions within the educational sector to see to it that these human resources personnel are encouraged and trained to help their junior counterparts practice and be involved in entrepreneurship skills acquisition programs.

It is upon this backdrop that the researchers were concerned with the following questions:

- Are there ways that educational stakeholders (administrators) could consciously manage educational employees (teachers) as human resources for direct tackling of the problem of poverty?

- If these human resources are properly managed and funded to aid the implementation of their entrepreneurial skills acquisition, will poverty reduction towards sustainable development goals be achieved

\subsection{Aims and Objectives of the Study}

The aim of this study was to examine management of secondary school principals for poverty reduction towards achievement of sustainable development goals. Specifically, the objectives of the study were to:

1. Determine ways educational administrators could contribute to poverty reduction.

2. Identify ways educational administrators could encourage other educational employees (teachers) to participate in poverty reduction for the achievement of sustainable development goals.

3. Find out how educational governing bodies and educational stakeholders can encourage educational employees to achieve sustainable development goals.

\subsection{Research Questions}

The following questions were formulated to guide the study:
1) In what ways could educational administrators contribute to poverty reduction for the achievement of sustainable development goals in secondary schools in Cross River State?

2) How could educational administrators manage the human resources personnel under them to contribute to poverty reduction for the achievement of sustainable development goals?

\subsection{Statement of Hypothesis}

$\mathrm{Ho}_{1}$ : There is no significant difference between the mean ratings of the responses of male and female administrators on the ways educational administrators could contribute towards poverty reduction for the achievement of sustainable development goals in secondary schools in Cross River State.

\section{Methodology}

The study adopted the survey design. The population of the study comprised 233 public secondary school principals in Cross River State. The study adopted purposive sampling technique (159 male principals and 74 female principals) who represented the respondents for the study. A questionnaire titled: Management of Secondary School Principals for Poverty Reduction in Achievement of Sustainable Development Goals (MSSPPRASDG) was designed by the researchers and validated by research experts in measurement and evaluation.

Data collected from 233 secondary school principals was used for the analysis. The questionnaire comprised 10 items. Using test-retest statistics, the reliability co-efficient of the instrument was 0.85 . Weighted mean score, standard deviation and criterion mean were used to answer the research questions while $\mathrm{z}$-test was used to test the hypotheses at 0.05 level of significance.

\section{Results}

Research Question: In what ways can educational administrators contribute to poverty reduction in the achievement of sustainable development goals in secondary schools in Cross River State?

The result in Table 2 revealed the responses of school administrators on ways educational administrators could contribute to poverty reduction for attainment of sustainable development goals. In each item, the sample mean (X) was compared with the criterion mean (U). If the sample mean is above the criterion mean, then that item is regarded as being accepted by principals as a way of reducing poverty. A close observation of items 1-5 showed that the response sample-mean ranged from 2.9-3.7 being greater than the criterion mean of 2.5. Furthermore, the grand mean of 3.33 , was still greater than 2.5 .

This implied that administrators have agreed on the items outlined as ways of reducing poverty in achieving sustainable development goals in schools.

This finding is in line with the assertion of Roberts (2014) who asserted that proper orientation of educational 
stakeholders, especially school administrators alongside their teachers and non-teaching personnel about the need for them to be the flag-bearers of entrepreneurship training and skill acquisition programmes is very necessary in the bid to achieve poverty reduction in sustainable development goals.

Table 2. Descriptive statistical analysis of school administrators' responses on the ways educational administrators could contribute to poverty reduction for the attainment of sustainable development goals in schools

\begin{tabular}{|c|c|c|c|c|c|c|c|c|}
\hline $\mathrm{S} / \mathbf{n}$ & Items & & & & & & & \\
\hline A & $\begin{array}{l}\text { The following ways are suggested as platforms for school principals } \\
\text { contribution to poverty reduction }\end{array}$ & SA & A & D & SD & $\ddot{\mathbf{X}}$ & $\mathbf{U}$ & Remark \\
\hline 1 & Provision of conducive environment for creative thinking & 436 & 276 & 40 & 12 & 3.2 & 2.5 & Agreed \\
\hline 2 & $\begin{array}{l}\text { Provision of innovative environment for staff development of } \\
\text { entrepreneurial skills }\end{array}$ & 612 & 147 & 36 & 13 & 3.4 & 2.5 & Agreed \\
\hline 3 & Provision of vocational training opportunities for staff & 456 & 186 & 74 & 20 & 2.9 & 2.5 & Agreed \\
\hline 4 & Involvement of staff in school-based innovative entrepreneurial activities & 732 & 120 & 20 & - & 3.7 & 2.5 & Agreed \\
\hline 5 & Involvement of staff in profitable school out-door services & 644 & 117 & 32 & 17 & 3.4 & 2.5 & Agreed \\
\hline
\end{tabular}

Grand mean $=3.33$.

Table 3. Descriptive statistical analysis of responses from school administrators' on strategies for managing human resources personnel for poverty reduction in achievement of sustainable development goals

\begin{tabular}{|c|c|c|c|c|c|c|c|c|}
\hline $\mathbf{S} / \mathbf{n}$ & Items & SA & A & D & SD & $\ddot{\mathbf{X}}$ & $\mathbf{U}$ & Remark \\
\hline B & $\begin{array}{l}\text { Indicate the extent to which you agree or disagree to administrators' role in } \\
\text { ensuring that human personnel are managed for poverty reduction towards } \\
\text { achievement of sustainable development goals. }\end{array}$ & & & & & & & \\
\hline 1 & $\begin{array}{l}\text { Liasing with government and other agencies for provision of soft loans and } \\
\text { grants to train personnel }\end{array}$ & 648 & 90 & 62 & 10 & 3.50 & 2.5 & Agreed \\
\hline 2 & $\begin{array}{l}\text { Utilization of staff trained in various vocational activities as resource } \\
\text { personnel in other retraining activities. }\end{array}$ & 472 & 169 & 66 & 29 & 3.15 & 2.5 & Agreed \\
\hline 3 & Ensuring that staff utilize skills and knowledge obtained in various activities & 596 & 159 & 46 & 8 & 3.47 & 2.5 & Agreed \\
\hline 4 & Provision of advanced training programmes on soft skills acquisition for staff & 328 & 369 & 46 & 5 & 3.2 & 2.5 & Agreed \\
\hline
\end{tabular}

Grand mean = 3.33.

Table 4. Z-test on the difference between mean score of male and female administrators on school administrators' contributions towards poverty reduction and achievement of sustainable development goals

\begin{tabular}{|c|c|c|c|c|c|c|}
\hline Variable & $\mathrm{N}$ & $\mathrm{X}$ & S.D & df & Z-cal & P-val \\
\hline \multirow[t]{2}{*}{ Male administrators } & 159 & 2.32 & 1.20 & & & \\
\hline & & & & 231 & 1.03 & .463 \\
\hline Female administrators & 74 & 2.29 & 1.27 & & & \\
\hline
\end{tabular}

* Significant at $0.05, \mathrm{df}=231$.

In the tables above, $\ddot{\mathrm{X}}$ and $\mathrm{U}$ are defined as the sample response mean and the criterion mean respectively.

The result in Table 3 revealed the responses of school administrators on administrators' role in ensuring that human resources personnel are managed for poverty reduction for sustainable development goals attainment. The result showed that the response sample mean ( $\ddot{\mathrm{X}})$ from items 1-4 is greater than the criterion mean (U) of 2.5. Further inspection still showed that the grand mean of 3.33 is greater than the criterion mean (2.5). This implied that administrators agreed on the items as a role of managing human personnel resources for poverty reduction and achievement of sustainable development goals.

This is in agreement with the submission of [13] who stated that education controlling bodies such as the Nigeria Union of Teachers (NUT), State Ministry of Education (SME) and State Secondary Education Board (SSEB), should not only encourage school administrators to engage their subordinates into in-service entrepreneurial and skills acquisition training programs but should work hand in hand with government to give grants, soft loans and long term loans to educational employees who have good and verifiable entrepreneurship ideas and proposals but are handicapped in achieving them, because of funding.

The result in Table 4 revealed that the mean value $(X=2.33)$ for male administrators is not relatively greater than the mean value $(X=2.29)$ for female administrators. This implies that there is no difference in male and female administrators' contributions towards poverty reduction. Furthermore, when these mean differences were compared using Z-test statistical analysis, the result obtained showed $(\mathrm{t}=1.03, \mathrm{p}>.05)$. Since $\mathrm{P}(.463)$ is greater than .05 , the null hypothesis which stated that there is no difference between the mean ratings of the responses of male and female administrators on the ways educational administrators could contribute towards poverty reduction 
for the achievement of sustainable development goals in secondary schools in Cross River State was therefore retained.

This research finding is in line with the assertion by [11] who expressed that in an era where opportunities for sustainable wealth creation can be easily harnessed and the introduction of entrepreneurship education into the school curriculum, so much may be achieved in terms of poverty reduction and economic growth if all teachers are involved in teaching and practicing the principles of entrepreneurship themselves by venturing and serving as evidence of financial independence and agents of poverty eradication.

\section{Conclusion}

Based on the findings of this study, the following conclusions were made:

1. Educational administrators who are encouraged with achievable and practical learning skills will contribute towards poverty reduction in the secondary schools where they head by introducing entrepreneurship in-service training programs for members of their staff.

2. Where educational administrators are properly motivated by educational governing bodies, through the provision of soft loans, grants and long term loans, then entrepreneurship in-service training programs towards poverty reduction and achievement of sustainable development goals will become a success.

\section{Recommendation}

Based on the findings of the study, the following recommendations were made:

1) Educational administrators should set up in-service and on-the-job entrepreneurship and skill acquisition training programs for members of their staff, so as to promote and enhance their financial independence for poverty reduction towards achievement of sustainable development goals.

2) Education governing bodies such as Federal Ministry of Education (FME), State Ministry Education (SME), State Secondary Education Board (SSEB),
Nigeria Union of Teachers (NUT), etcetera should encourage school administrators who already have entrepreneurship training programs for members of their staff to obtain soft - loans, grants and long term loans to help already trained staff establish small and medium scale enterprises that will help in poverty reduction for the achievement of sustainable development goals in Cross River State, Nigeria.

\section{References}

[1] Copenhagen Declarations (retrieved on Wikipedia, $19^{\text {th }}$ April, 2013).

[2] Uko, E.S. \& Ayuk, A. A (2014). The Malaise that maligns the attainment of educational goals by the African child. The Nigerian Experience. International Journal of Education and Research. 2(7), 433-446.

[3] Ebua, H. I. (2014). Understanding economics of Nigeria Education. Lagos: Riders printing press.

[4] Obanya, P. (2014). Educationeering. Ibadan: HEBN Publishers.

[5] United Nations (2005). Decade of education for sustainable development. Link between the Global initiative in education http//www.unesco.org/education/desal.

[6] Samuel, O. S. (2010). Allocation of resources, methodology of educational administration and planning Port Harcourt, Nigeria.

[7] Federal Office of Statistics (2007). The Nigerian Household, Lagos, Nigeria. FOS Publications.

[8] Central Bank of Nigeria (2003). An Appraisal of Federal Government's poverty reduction educational programs. The Bullion. Lagos, Nigeria.

[9] Roberts, B. R. (2014). Politics of secondary school management. Jos: Power press.

[10] Arinze E. E (2015). Economics of Nigeria and Educational Impact International review of educational research papers 5(4), 270-279.

[11] Trance, C. T. (2015). Concept of Sustainability: origin, extension and usefulness for policy, natural resources and society. Oxford: Oxford University press.

[12] Udida L. A, Ebuara V. O, Uko E. S (2010). Accessing Factors Inhibiting Management of Higher Education for Poverty Alleviation in Southern Nigeria. Spoleczenstwo Rodzina. Published by Faculty of Social Science, Stalow. The John Paul II Catholic University of Lublia, Poland 23(2), 23-32.

[13] Roe, A. A. (2015). Principles of effective administration. Calabar: Zidak Publishers.

[14] Uko E. S (2013). Examination Malpractice: The Monster that plagues the Nigerian Education System in Soji Oni (Ed). Challenges and prospects in African Education System. Trafford Publishers, USA 675-695.

[15] Nkang, I.E (2008). Management of Basic Education for Poverty Alleviation in Akwa Ibom State of Nigeria. Nigerian Journal of Educational Administration and Planning.

[16] Roberts, B. R. (2014). Politics of secondary school management. Jos: Power press. 